\title{
An Evaluation to the Awareness of Family Medicine Residents in Ankara for the Coagulation Testing, Anticoagulation Treatment and Tracking
}

\author{
Ankara'daki Aile Hekimliği Asistanlarının Koagülasyon Testleri, \\ Antikoagülasyon Tedavisi ve Takibi Konusundaki \\ Farkındalıklarının Değerlendirilmesi
}

İskender Bülbül' ${ }^{1}$ İrfan Șencan², İsmail Kasım², Tarik Eren Yilmaz², Adem Bahadir³, Adem Ozkara²

${ }^{1}$ Aksaray Number 14 Family Health Center

${ }^{2}$ Ankara Numune Resarch and Education Hospital

3Rize Number 11 Family Health Center

\begin{abstract}
Objectives: The family physicians are the individuals who constitute the first contact point with patients and take position in primary care. On behalf of family physicians are dominating by a wide range of disease groups, reveal the awareness of the anticoagulant therapy and monitoring necessary. Materials and Methods: Research was planned as an observational, cross sectional survey. Surveys were hand out to family physician residents in Ankara. 143 participants answering the questions of survey without any reserve from assistant family physician, who were invited to our study date between 15/10/2014 and 12/01/2014, were incorporated.

Results: Only $8.4 \%$ of the residents stated that they attended a training on anticoagulant therapy and follow-up. We pick out that participants who attend training have more accurate answer to questions which intended to measure awareness and knowledge. Those constituted the majority who has not completed 10 years in their medical profession. The correct answer rates of the group that we call young physicians were higher.

Conclusion: With this research, the awareness about anticoagulant therapy and monitoring and lack of education are reveal. With the researches supporting this study, identifying the lacking issues that residents of family physicians' awareness then making education plans intended to these issues and better equipped family physician residents giving medical service will be provided.

Key words: Family Physician, Coagulation Test, Anticoagulation Therapy and Monitoring
\end{abstract}

Öz

Amaç: Aile hekimliği uzmanları, hastalarla ilk temas noktasını olușturan birinci basamakta görev alan sağlık neferleridir. Uzmanlık eğitim sürecini birçok eğitim aşamasından geçirerek tamamlayan hekimler 3 yıl boyunca bir bilgi birikimi kazanırlar. Aile hekimliği uzmanlarının geniș bir yelpazedeki hastalık grubuna hakim olmaları adına antikoagülan tedavi ve takibi hakkında farkındalıklarının ortaya konması gerekmektedir.

Materyal ve Metot: Araştırma gözlemsel, kesitsel bir anket çalışması olarak planladı. Ankara'daki aile hekimliği asistanlarına, özellikle eğitim saatlerinde, anketler dağıtıldı. o1/9/2014 ile o1/12/2014 tarihleri arasında çalıșmamıza davet edilen asistan hekimlerden anket sorularına eksiksiz yanıt veren 143 katılımcı araștırmaya dahil edildi.

Bulgular: Araştırmaya katılımcıların büyük çoğunluğu genç hekimlerden oluşmaktaydı. Asistan hekimlerin sadece $\% 8,4$ ü antikoagülan tedavi ve takibi ile ilgili bir eğitime katıldığını ifade etti. Katılımcılardan eğitime katılanların bilgi düzeyi ve farkındalıklarını ölçmeye yönelik olan sorulara daha doğru yanıtlar verdiğini gördük. Hekimlik mesleğinde 10 yılını doldurmamış olanlar çoğunluğu oluşturmaktaydı. Genç hekimler grubunun soruları doğru cevaplama oranları daha yüksekti.

Sonuç: $\mathrm{Bu}$ araștırma ile antikoagülan tedavi ve takibi konusunda farkındalık ve eğitim eksikliği ortaya konulmuştur. Bu çalıșmayı destekleyici araştırmalar ile aile hekimliği asistanlarının farkındalıklarının eksik olduğu konular belirlenerek bu konulara yönelik eğitim planlarının yapılması daha donanımlı aile hekimliği uzmanlarının sağlık hizmeti vermesini sağlayacaktır.

Anahtar Kelimeler: Ankara'daki Aile Hekimliği Asistanları, Koagülasyon Testleri, Antikoagülan Tedavi ve Takibi 
An Evaluation to the Awareness of Family Medicine Residents in Ankara for the Coagulation Testing, Anticoagulation Treatment and Tracking

Yazıșma Adresi / Correspondence:

Dr. İskender Bülbül

e-mail: iskenderbulbul@hotmail.com

Date of submission: 17.02.2019

Date of admission: 18.03 .2019

\section{Introduction}

Arterial and venous thrombosis is a critic complication emerging during medical therapy and after surgeries. Thromboses are among of the major causes of mortality and morbidity. In the United States (USA), an average of 75,000 people experiences thrombotic events each year and 9,ooo of these events result in death. Thromboses arise from the impairment of vascular integrity and the induction of tissue factor pathway and platelets in the vascular cell-induced coagulation system. Venous thrombosis is most commonly caused by lethal pulmonary embolism (PE) and postphlebitic syndrome; Arterial thrombosis is the most common cause of myocardial infarction, stroke, and extremity gangrene. ${ }^{1}$ The thrombotic event is the result of a complex balanced relationship between blood vessel, fibrinolytic system, coagulation system and platelets. Venous thromboembolism is an important cause of mortality and morbidity, which is reported to be $1 / 1000$ in developed countries but rises to $1 / 100$ in older ages. ${ }^{2}$ And, because of thromboses developing in the lower extremity, there is a possibility of development of pulmonary embolism by $1-5 \%$, resulting in an important mortality reason. There are many pharmacological agents that inhibit thrombus formation or reduce the clinical consequences of formed thrombosis. Antithrombotic therapy is a care that should be given carefully because of the presence of new pharmacological agents and various combinations. Treatments given for this purpose are collected in three groups as anticoagulant drugs, antithrombotic drugs and thrombolytic drugs. The most commonly used anticoagulant (AC). drugs are nonfractional (NF) standard-heparin, low-molecular-weight (LMW) heparin and warfarin that derive from coumarin. New ones are being added to AC drugs each passing day.

The health reform initiative, which started in the 1960 s and where the first stage was forerunner, has intensified its intensity in the last 20 years. The reform debates in health bring forward the family practice specialization education before the first phase of development. Family practice specialty education that entered the statue of specialty in medicine in the Republic of Turkey in 1983 has begun to recruiting assistants to education and research hospitals in 1985 and in the beginning of 1989 , for the first time, family medicine residents (FMR) received their expertise.

The legislation, which has been working for a long time and which is indisputable in contributing to family medicine specialty training, was made in 2010 and the family medicine specialization training process, has entered a new turn. With this arrangement, the mandatory rotations in the family medicine specialty training have been reduced to 18 months, and the remaining 18 months have been devoted to field family medicine practice training. The knowledge gained in the implementation of mandatory rotation and experiences in the field has the objective of pursuing an aim to train specialist doctors ready for situations encountered in primary care.

Considering that diagnosis and treatment habits of specialist doctors are acquired during the assistant period, it is necessary to acquire the habit of closely following the 
current diagnosis and treatment plans to a specialist family physician in this period. One of the most important tasks of the family physician specialist who is the pupil of the first stage should be to know thrombosis conditions, which is one of the issues with high mortality and morbidity, and therefore the coagulation tests to be used in these situations, the situations that can ruin these tests, the current anticoagulant treatments and the complications that may be encountered during treatment. In this study, we aimed to find out whether this consciousness developed in FMR working in Ankara and to show the correct and wrong applications made in this issue and to search for the answer "Is FMR need a training on thrombosis?". The results of the discussion of the study, either in the name of medical science or on behalf of distinguished professors who have committed their lives to education, the fact that contributed to the rise in the level of FMR in Turkey has emerged as a targeted our secondary goal.

\section{Material and Methods}

\section{Preparation of Survey Questions}

The research was planned as an observational and cross-sectional survey study. Literature search about coagulation tests, anticoagulation treatments and its tracking were conducted and the original questionnaire for the study was prepared by the researcher and co-investigator (ANNEX-1). Pilot work was started after the survey preparation was completed. A pilot study was conducted primarily through 15 FMR in order to obtain the desired answers in the survey questions and to provide a clear understanding of the participants' questions. Upon the reply of the questions in an understandable way, we passed the permission phase for research. Ankara Numune Training and Research Hospital ethics committee approved the study (E-14-342).

\section{Implementation of the Survey}

Since there were some questions about the level of knowledge of the participants in the prepared questionnaire, personal information was not included in the questionnaire and the questions were tried to be answered freely without being pressured. In the questionnaire, preliminary information for the FMR was made primarily. Participants who approve the preliminary information were first asked questions about socio-demographic characteristics. Participants that completed the socio-demographic information were asked questions about the coagulation tests, the situations in which these tests were required, the normal ranges in the tracking of the tests, the drugs used in anticoagulation therapy and how to follow up these drugs. Questionnaires of 56 participants who did not respond to one or more of the questionnaires we reached to 199 were excluded from the evaluation. The questionnaires of 143 participants who answered the question completely were considered valid and taken into consideration.

\section{Population and Sample Selection}

Istanbul and Ankara where the cities that have most of the Family Medicine Clinic Center and Assistant Doctors in Turkey are determined as a population, but the city of Ankara was chosen in the scope of this study because it is the capital city of the country, the center of the Ministry of Health and ease of transportation. The population of the research was identified as assistant doctors working in Family 
An Evaluation to the Awareness of Family Medicine Residents in Ankara for the Coagulation Testing, Anticoagulation Treatment and Tracking

Medicine Clinics in Ankara. Twenty-one questions, consisting of 13 multiple-choice questions and of 8 yes-no-not-sure choices, were answered by respondents who read consciously.

The study was conducted between October 15, 2014 and December 1, 2014. During the period of the study, the number of persons serving as assistants of Family Medicine in Ankara was 62 at the Ankara Numune EAH Family Medicine Clinic, Ministry of Health Yıldırım Beyazıt University Ankara Atatürk EAH Family Medicine Clinic 56, Ankara Dışkapı Yıldırım Beyazıt EAH Family Medicine Clinic 28, Ankara EAH Family Medicine Clinic 26, Ankara Keçiören EAH Family Medicine Clinic 8, Ankara University Faculty of Medicine 22 at Family Medicine Clinic, 1 at Hacettepe University Medical Faculty Family Medicine Clinic, 1 at Turgut Özal University Medical Faculty Family Medicine Clinic, and 12 at Gülhane Military Medical Academy Family Medicine Clinic. There were 216 people in total. The sample size was calculated to be at least 139 people with an acceptable error of $5 \%$, confidence level of $95 \%$. A total of 216 people were surveyed. 143 people were included in the study to answer questions fully and more than the targeted sample size was reached.

\section{Statistical Analysis}

Differences between the categorical variables were assessed with chi-square, chisquare likelihood ratio, or Fisher's exact chi-square. SPSS Statistics Ver. 17.o (SPSS Inc. Chicago, IL, USA) program was used for all statistical analysis and calculations. A statistical significance of $\mathrm{p}<0.05$ was accepted as the indicator of the statistical analysis.

\section{Results}

Correct and incorrect answers given by family physician residents during the period of medical practice (Figure 1). 143 FMR, which responded to the questionnaire completely, was admitted to the survey. Gender and time that they are physicians of the assistant doctors who are included in the study are given in Table 1.

Table 1. Years of family medicine residents based by Sex

\begin{tabular}{|c|c|c|c|}
\hline Medical Year & $\begin{array}{c}\text { Women }(\mathbf{n}: \mathbf{9 4}) \\
\mathbf{\%}(\mathbf{n})\end{array}$ & $\begin{array}{c}\text { men }(\mathbf{n}: 49) \\
\%(\mathbf{n})\end{array}$ & $\begin{array}{c}\text { Total }(\mathbf{N}: \mathbf{1 4 3}) \\
\mathbf{\%}(\mathbf{n})\end{array}$ \\
\hline $\mathbf{1 - 5}$ years & $69.70(69)$ & $30.30(30)$ & $100(99)$ \\
\hline 6-10 years & $55.20(16)$ & $44.80(13)$ & $100(29)$ \\
\hline $11-15$ years & $44.40(4)$ & $55.60(5)$ & $100(9)$ \\
\hline $16-20$ years & $100(4)$ & $0(0)$ & $100(4)$ \\
\hline $20>$ & $50(1)$ & $50(1)$ & $100(2)$ \\
\hline
\end{tabular}

No significant differences was found between the time that the assistants of the family medicine resided and the correct response of the International Normalized Ratio (INR) test to the duration of the examination (Figure 1). Borderline significant relationship found between attending any educational activity for anticoagulant treatment and INR management and initiating Warfarin treatment based on diagnosis $\left(\chi^{2}=3.899 ; \mathrm{p}=\right.$ o.o48). The rates of participation status of education and starting warfarin sodium are shown in Table 2 as comparative. 


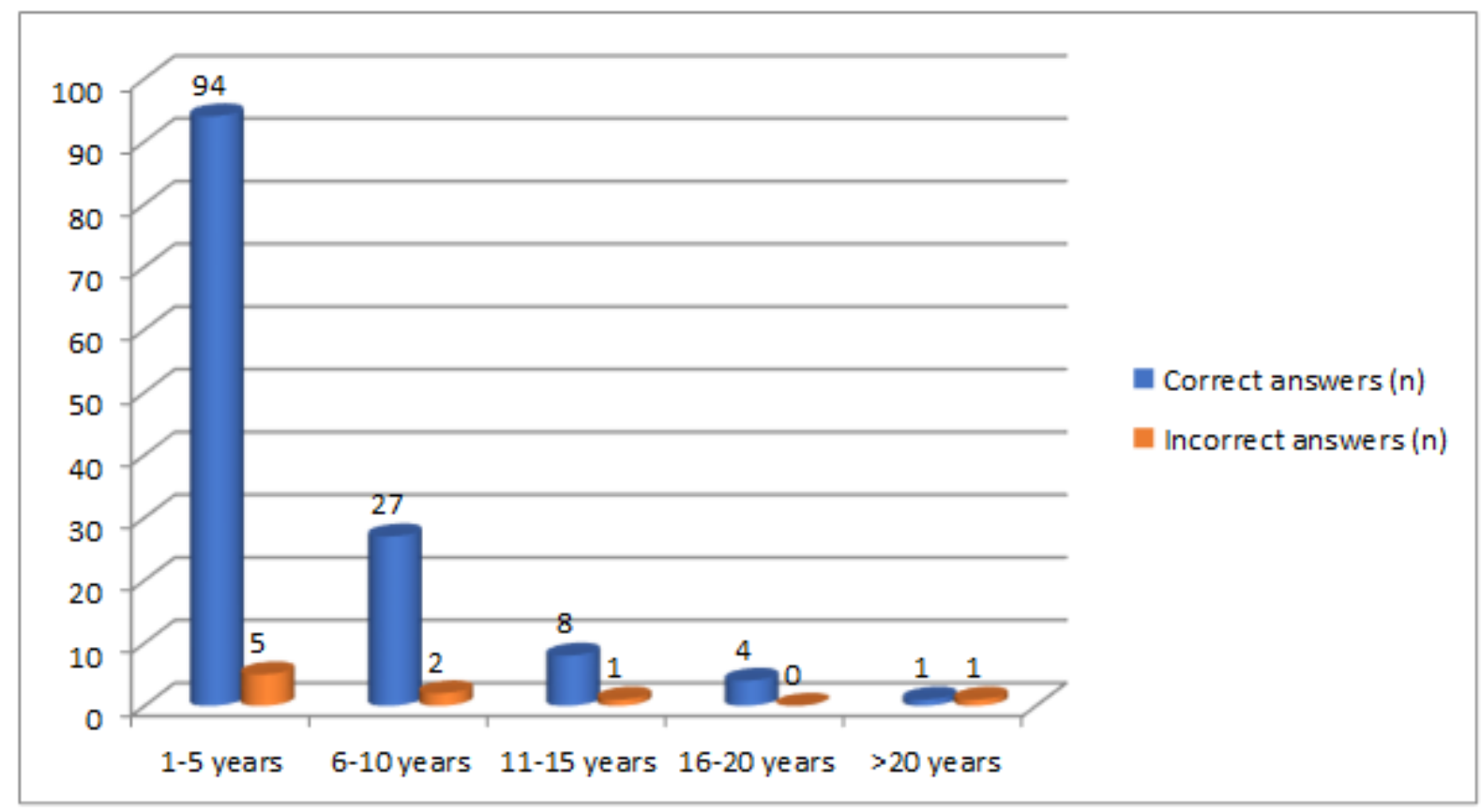

Figure 1. Correct and incorrect answers given by family physician residents during the period of medical practice.

Table 2. Educational status of family medicine residents in Ankara regarding anticoagulant treatment and follow-up, and indication rates for warfarin sodium.

\begin{tabular}{|l|c|c|c|}
\hline $\begin{array}{l}\text { Warfarin Sodium } \\
\text { starting }\end{array}$ & $\begin{array}{c}\text { Trained } \\
\%(\mathbf{n})\end{array}$ & $\begin{array}{c}\text { Non-trained } \\
\%(\mathbf{n})\end{array}$ & $\begin{array}{c}\text { Total } \\
\%(\mathbf{n})\end{array}$ \\
\hline Yes & $28.60(2)$ & $71.40(5)$ & $100(7)$ \\
\hline No & $7.40(10)$ & $92.60(126)$ & $100(136)$ \\
\hline Total & $\mathbf{8 . 4 0}(12)$ & $\mathbf{9 1 . 6 0 ( 1 3 1 )}$ & $100(143)$ \\
\hline
\end{tabular}

A statistically significant relationship was found between the presence of an education related to anticoagulant therapy and INR tracking and the accuracy of opinions on whether vascular disease is a risk factor for the initiation of warfarin sodium $\left(\chi^{2}=\right.$ $6.242 ; p=0.044)$. A statistically significant relationship $\left(\chi^{2}=6.636 ; p=0.036\right)$ was found between the inclusion of an education on anticoagulant therapy and tracking of the INR, and the accuracy of opinions about whether ages between 65 and 74 were risk factors for the initiation of warfarin sodium. The relationship between participants' attitudes to medication, anticoagulant therapy and tracking, and responses to risky situations to start warfarin sodium are given in Table 3.

A statistically significant relationship was found between the time the participants were physicians and the correctness of the response to the need for an INR test if there was prolonged nosebleed $\left(\chi^{2}=17.407 ; p=0.026\right)$. A statistically significant relationship was found between the accuracy of responses to the necessity of having an INR test ( $\chi^{2}$ $=16.084 ; \mathrm{p}=0.041)$ in case of severe gingival hemorrhage with the duration of the medical practice. A statistically significant relationship was found between the accuracy of the responses to the necessity of taking the INR test $\left(\chi^{2}=16.256 ; p=0.039\right)$ 
An Evaluation to the Awareness of Family Medicine Residents in Ankara for the Coagulation Testing, Anticoagulation Treatment and Tracking

when there was an unusual increase in menstrual bleeding with the duration of the medical practice.

Table 3. The relationship between the answers given to the cases that are risky to start warfarin sodium and stating the training

\begin{tabular}{|c|c|c|c|c|c|c|c|c|c|}
\hline \multirow[b]{2}{*}{ Risks } & \multicolumn{3}{|c|}{ Trained } & \multicolumn{6}{|c|}{ Time of working as physician } \\
\hline & $\begin{array}{l}\text { Yes } \\
\%(n)\end{array}$ & $\begin{array}{l}\text { No } \\
\%(n)\end{array}$ & $\mathbf{P}$ & $\begin{array}{c}1-5 \\
\text { years } \\
\%(n) \\
\end{array}$ & $\begin{array}{c}\text { 6-10 } \\
\text { years } \\
\%(n)\end{array}$ & 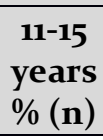 & $\begin{array}{l}16-20 \\
\text { years } \\
\%(n) \\
\end{array}$ & $\begin{array}{l}>20 \\
\%(n)\end{array}$ & $\mathbf{P}$ \\
\hline $\begin{array}{l}\text { Congestive } \\
\text { Heart Failure - } \\
\text { Left Ventricular } \\
\text { Dysfunction }\end{array}$ & $\begin{array}{l}9.80 \\
(5)\end{array}$ & $\begin{array}{c}90.20 \\
(46)\end{array}$ & 0.694 & $\begin{array}{c}72.50 \\
(37)\end{array}$ & $\begin{array}{c}23.50 \\
(12)\end{array}$ & $\begin{array}{c}2 \\
(1)\end{array}$ & $\begin{array}{c}2 \\
(1)\end{array}$ & $\begin{array}{c}0 \\
(\mathrm{o})\end{array}$ & 0.216 \\
\hline Hypertension & $\begin{array}{r}9 \cdot 50 \\
(7)\end{array}$ & $\begin{array}{c}90.50 \\
(67)\end{array}$ & 0.428 & $\begin{array}{r}67.60 \\
(50) \\
\end{array}$ & $\begin{array}{r}21.60 \\
(16)\end{array}$ & $\begin{array}{r}6.80 \\
(5)\end{array}$ & $1.30(1)$ & $\begin{array}{r}2.70 \\
(2)\end{array}$ & 0.264 \\
\hline Ages $>75$ & $\begin{array}{r}12.50 \\
(7) \\
\end{array}$ & $\begin{array}{r}87.50 \\
(49) \\
\end{array}$ & 0.264 & $\begin{array}{r}76.80 \\
(43) \\
\end{array}$ & $\begin{array}{r}16.10 \\
(9) \\
\end{array}$ & $\begin{array}{r}5 \cdot 30 \\
(3) \\
\end{array}$ & $\begin{array}{c}0 \\
\text { (o) }\end{array}$ & $\begin{array}{r}1.80 \\
(1) \\
\end{array}$ & 0.341 \\
\hline $\begin{array}{l}\text { Diabetes } \\
\text { Mellitus }\end{array}$ & $\begin{array}{r}8.80 \\
(7)\end{array}$ & $\begin{array}{r}91.20 \\
(73) \\
\end{array}$ & 0.624 & $\begin{array}{r}70 \\
(56) \\
\end{array}$ & $\begin{array}{r}23.80 \\
(4)\end{array}$ & $\begin{array}{r}5 \\
(4) \\
\end{array}$ & $\begin{array}{l}\mathrm{o} \\
(\mathrm{o})\end{array}$ & $\begin{array}{r}1.20 \\
(1)\end{array}$ & 0.130 \\
\hline $\begin{array}{l}\text { Stroke Thrombo } \\
\text { embolism }\end{array}$ & $\begin{array}{l}4.80 \\
(2)\end{array}$ & $\begin{array}{c}95.20 \\
(40)\end{array}$ & 0.267 & $\begin{array}{c}54.70 \\
(23)\end{array}$ & $\begin{array}{c}38.10 \\
(16)\end{array}$ & $\begin{array}{l}4.80 \\
(2)\end{array}$ & $\begin{array}{c}2.40 \\
(1)\end{array}$ & $\begin{array}{c} \\
\text { o } \\
(0)\end{array}$ & 0.108 \\
\hline $\begin{array}{l}\text { Vascular } \\
\text { Diseases }\end{array}$ & $\begin{array}{r}2.50 \\
(1) \\
\end{array}$ & $\begin{array}{r}97.50 \\
(39)\end{array}$ & 0.044 & $\begin{array}{l}60 \\
(24)\end{array}$ & $\begin{array}{r}32.50 \\
(13)\end{array}$ & $\begin{array}{r}5 \\
(2) \\
\end{array}$ & $\begin{array}{r}2.50 \\
(1) \\
\end{array}$ & $\begin{array}{c}0 \\
(0)\end{array}$ & 0.424 \\
\hline Age: $65-74$ & $\begin{array}{r}14.10 \\
(10) \\
\end{array}$ & $\begin{array}{r}85.90 \\
(61) \\
\end{array}$ & 0.036 & $\begin{array}{r}71.80 \\
(51) \\
\end{array}$ & $\begin{array}{r}22.50 \\
(16) \\
\end{array}$ & $\begin{array}{r}4.20 \\
(3) \\
\end{array}$ & $\begin{array}{l}0 \\
(\mathrm{o}) \\
\end{array}$ & $\begin{array}{r}1.50 \\
(1) \\
\end{array}$ & 0.089 \\
\hline Women & $\begin{array}{r}10.60 \\
(9)\end{array}$ & $\begin{array}{r}89.40 \\
(76) \\
\end{array}$ & 0.252 & $\begin{array}{r}72.90 \\
(62) \\
\end{array}$ & $\begin{array}{r}21.20 \\
(18) \\
\end{array}$ & $\begin{array}{r}4.70 \\
(4)\end{array}$ & $\begin{array}{l}0 \\
(\mathrm{o})\end{array}$ & $\begin{array}{r}1.20 \\
(1)\end{array}$ & 0.209 \\
\hline
\end{tabular}

A statistically significant relationship was found between the duration of the medical practice performed by the participants and the correctness of the response to the necessity of taking the INR test in the case of morbidity $\left(\chi^{2}=18.340 ; \mathrm{p}=0.019\right)$ (Table 4).

A statistically significant correlation was found between the accuracy of the answers given to the question whether the duration of the medical practice and the hyperthyroidism would increase the INR value $\left(\chi^{2}=20.013, p=0.010\right)$. A statistically significant relationship was found between participants' medical history and the accuracy of the answers to the question whether the collagen vascular diseases would increase the INR value $\left(\chi^{2}=15.945 ; p=0.043\right)$. A statistically significant correlation was found between the accuracy of the answers given to the question whether the duration of the medical practice would increase the INR value of diarrhea $\left(\chi^{2}=17.272 ; \mathrm{p}=\right.$ 0.027 ). A statistically significant relationship was found between participants' medical history and the accuracy of the answers given to the question whether alcohol would reduce INR value $\left(\chi^{2}=17.221 ; p=0.028\right)$. A statistically significant relationship was found between the correctness of the answers to the question asked by patients who were taking warfarin sodium and whether they should be referred to an upper step in the event of spontaneous gingiva, nasal bleeding, idiopathic or fecal bleeding, with an education on anticoagulant therapy and INR tracking $\left(\chi^{2}=8.834 ; \mathrm{p}=0.003\right)$. 
An Evaluation to the Awareness of Family Medicine Residents in Ankara for the Coagulation Testing, Anticoagulation Treatment and Tracking

Table 4. The relationship between the rates of participation in the training of INR followers and the situations where INR audits are required

\begin{tabular}{|c|c|c|c|c|c|c|c|c|c|}
\hline \multirow[b]{2}{*}{ Cases } & \multicolumn{3}{|c|}{ Trained } & \multicolumn{6}{|c|}{ Time of working as physcian } \\
\hline & $\begin{array}{l}\text { Yes } \\
\%(n)\end{array}$ & $\begin{array}{l}\text { No } \\
\%(n)\end{array}$ & $\mathbf{P}$ & $\begin{array}{c}1-5 \\
\text { years } \\
\%(n)\end{array}$ & $\begin{array}{c}6-10 \\
\text { years } \\
\%(n)\end{array}$ & $\begin{array}{c}11-15 \\
\text { years } \\
\%(n)\end{array}$ & $\begin{array}{l}16-20 \\
\text { years } \\
\%(n)\end{array}$ & $\begin{array}{c}>20 \\
\% \\
(n)\end{array}$ & $\mathbf{P}$ \\
\hline $\begin{array}{l}\text { Prolonged Nose } \\
\text { Bleeding }\end{array}$ & $9.50(12)$ & $\begin{array}{c}90.5 \\
0(114) \\
\end{array}$ & 0.204 & $\begin{array}{c}69.80 \\
(88)\end{array}$ & $\begin{array}{c}22.20 \\
(28)\end{array}$ & $\begin{array}{c}4.80 \\
(6)\end{array}$ & $1.60(2)$ & $\begin{array}{c}1.60 \\
(2)\end{array}$ & 0.026 \\
\hline $\begin{array}{l}\text { Bloody } \\
\text { Vomiting }\end{array}$ & $5.60(4)$ & $\begin{array}{c}94.40 \\
(68)\end{array}$ & 0.424 & $\begin{array}{c}69.40 \\
(50)\end{array}$ & $\begin{array}{c}23.60 \\
(17)\end{array}$ & $\begin{array}{c}4.20 \\
(3)\end{array}$ & $\begin{array}{c}2.80 \\
(2)\end{array}$ & $\begin{array}{c}0 \\
(0)\end{array}$ & 0.233 \\
\hline Bloody Saliva & $5.60(3)$ & $\begin{array}{c}94.40 \\
(51) \\
\end{array}$ & 0.566 & $\begin{array}{c}59 \cdot 30 \\
(32) \\
\end{array}$ & $\begin{array}{c}31.50 \\
(17) \\
\end{array}$ & $\begin{array}{c}5 \cdot 50 \\
(3) \\
\end{array}$ & $\begin{array}{c}3 \cdot 70 \\
(2) \\
\end{array}$ & $\begin{array}{c}0 \\
(0) \\
\end{array}$ & 0.059 \\
\hline Blood in Urine & $\begin{array}{c}6 \\
(5) \\
\end{array}$ & $94(78)$ & 0.056 & $\begin{array}{c}67.50 \\
(56) \\
\end{array}$ & $\begin{array}{c}24.10 \\
(20) \\
\end{array}$ & $\begin{array}{c}4.80 \\
(4)\end{array}$ & $\begin{array}{c}3.60 \\
(3)\end{array}$ & $\begin{array}{c}0 \\
(0) \\
\end{array}$ & 0.226 \\
\hline $\begin{array}{l}\text { Unusual } \\
\text { Headache }\end{array}$ & $3.90(2)$ & $\begin{array}{c}96.10 \\
(41)\end{array}$ & 0.218 & $\begin{array}{c}62.70 \\
(32)\end{array}$ & $\begin{array}{c}29.40 \\
(15)\end{array}$ & $\begin{array}{l}3.90 \\
(2)\end{array}$ & $\begin{array}{c}2 \\
(1)\end{array}$ & $\begin{array}{c}2 \\
(1) \\
\end{array}$ & 0.055 \\
\hline $\begin{array}{l}\text { Increased } \\
\text { Menstrual } \\
\text { Bleeding }\end{array}$ & $6.10(6)$ & $\begin{array}{c}93.90 \\
(93)\end{array}$ & 0.116 & $\begin{array}{c}69.70 \\
(69)\end{array}$ & $\begin{array}{c}24 \cdot 30 \\
(24)\end{array}$ & $\begin{array}{l}4 \\
(4)\end{array}$ & $\begin{array}{c}2 \\
(2)\end{array}$ & $\begin{array}{c}0 \\
(0)\end{array}$ & 0.039 \\
\hline Cyanosis & $8.30(10)$ & $\begin{array}{l}91.70 \\
(110)\end{array}$ & 0.206 & $\begin{array}{c}63.80 \\
(82) \\
\end{array}$ & $\begin{array}{c}22.50 \\
(27) \\
\end{array}$ & $\begin{array}{c}6.70 \\
(8) \\
\end{array}$ & $\begin{array}{c}0.80 \\
(1)\end{array}$ & $\begin{array}{c}1.70 \\
(2) \\
\end{array}$ & 0.019 \\
\hline $\begin{array}{l}\text { Severe Gum } \\
\text { Bleeding }\end{array}$ & $8.90(11)$ & $\begin{array}{l}91.10 \\
(113)\end{array}$ & 0.439 & $\begin{array}{c}67.70 \\
(84) \\
\end{array}$ & $\begin{array}{c}23.40 \\
(29) \\
\end{array}$ & $\begin{array}{c}5.70 \\
(7)\end{array}$ & $\begin{array}{c}1.60 \\
(2)\end{array}$ & $\begin{array}{c}1.60 \\
(2)\end{array}$ & 0.041 \\
\hline Black Stool & $6.20(5)$ & $\begin{array}{c}93.80 \\
(76)\end{array}$ & 0.487 & $\begin{array}{c}69.20 \\
(56)\end{array}$ & $\begin{array}{c}24.70 \\
(6)\end{array}$ & $\begin{array}{c}3 \cdot 70 \\
(3)\end{array}$ & $\begin{array}{c}1.20 \\
(1)\end{array}$ & $\begin{array}{c}1.20 \\
(1)\end{array}$ & 0.127 \\
\hline
\end{tabular}

A statistically significant relationship was found between the accuracy of the answers given to the question that asked patients to use warfarin sodium if they had an INR of more than 5 and spontaneous gingiva, nasal bleeding, urination or fecal blood, $(\mathrm{P}=$ o.o16) (Table 5).

A statistically significant relationship was found between the accuracy of the answers to the question we asked about the need to be warned of being prescribed from tricyclic antidepressants to patients using warfarin sodium with anticoagulant therapy and an INR tracking trait $\left(\chi_{2}=6.81, p=0.014\right)$. There was a statistically significant correlation between the accuracy of the answers given to the questions we were asking about whether to use the tracking with INR examination $\left(\chi_{2}=5.872 ; \mathrm{p}=0.015\right)$ (Table 6).

\section{Discussion}

The FMR, including those who did not work, had indicated a significant relationship between their warfarin sodium intakes for the first time, with indications of any education attendance related to anticoagulant therapy and INR tracking. It has been determined that warfarin sodium does not start by specifying the indications of a large majority of such training sites. The fact that trained physicians can act more courageously in starting the medication is an important consequence of our encounter. This may be related to the lack of confidence in the physicians themselves. It is the strongest indicator of a significant difference between educated and non-trained. However, the concept of education, which is taken as a limitation of our work, is based on the interpretation that the participant himself or herself has received education, 
An Evaluation to the Awareness of Family Medicine Residents in Ankara for the Coagulation Testing, Anticoagulation Treatment and Tracking

and this educational concept does not contain a standard. For this reason, it is appropriate to conduct an evaluation after the participant's standard training to determine the effect of education clearly in similar studies.

Table 5. The results showing the necessity of referring the patients using warfarin sodium to an upper step

\begin{tabular}{|c|c|c|c|c|c|c|c|c|c|}
\hline \multirow[b]{2}{*}{ Cases } & \multicolumn{3}{|c|}{ Trained } & \multicolumn{6}{|c|}{ Time of working as physcian } \\
\hline & $\begin{array}{l}\text { Yes } \\
\%(n)\end{array}$ & $\begin{array}{l}\text { No } \\
\%(n)\end{array}$ & $\mathbf{P}$ & $\begin{array}{c}1-5 \\
\text { years } \\
\%(n) \\
\end{array}$ & $\begin{array}{c}\text { 6-1o } \\
\text { years } \\
\%(\mathbf{n})\end{array}$ & $\begin{array}{c}11-15 \\
\text { years } \\
\%(n)\end{array}$ & $\begin{array}{l}\text { 16-2o } \\
\text { years } \\
\%(n)\end{array}$ & $\begin{array}{c}>20 \\
\%(n)\end{array}$ & $\mathbf{P}$ \\
\hline INR $>10$ & $\begin{array}{c}7.90 \\
\text { (11) }\end{array}$ & $\begin{array}{l}92.10 \\
(129)\end{array}$ & 0.601 & $\begin{array}{c}68.60 \\
(96)\end{array}$ & $\begin{array}{c}20.70 \\
(29)\end{array}$ & $\begin{array}{c}6.40 \\
(9)\end{array}$ & $\begin{array}{c}2.90 \\
(4)\end{array}$ & $\begin{array}{l}1.40 \\
(2)\end{array}$ & 0.693 \\
\hline $\begin{array}{l}\text { Spontaneously } \\
\text { bleeding }\end{array}$ & $\begin{array}{c}3 \cdot 30 \\
(3)\end{array}$ & $\begin{array}{c}96.70 \\
(89)\end{array}$ & 0.003 & $\begin{array}{c}69.60 \\
(64)\end{array}$ & $\begin{array}{c}19.60 \\
(18)\end{array}$ & $\begin{array}{l}5.40 \\
(5)\end{array}$ & $\begin{array}{l}3.20 \\
(3)\end{array}$ & $\begin{array}{l}2.20 \\
(2)\end{array}$ & 0.674 \\
\hline INR $>5$ & $\begin{array}{l}10.40 \\
(12)\end{array}$ & $\begin{array}{c}89.60 \\
(86)\end{array}$ & 0.212 & $\begin{array}{l}69.8 \\
(67)\end{array}$ & $\begin{array}{c}20.80 \\
(20)\end{array}$ & $\begin{array}{l}3.1 \\
(3)\end{array}$ & $\begin{array}{l}4.20 \\
(4)\end{array}$ & $\begin{array}{l}2.10 \\
(2)\end{array}$ & 0.058 \\
\hline $\begin{array}{l}\text { INR }>5 \text { and } \\
\text { spontaneously } \\
\text { bleeding }\end{array}$ & $\begin{array}{l}8.60 \\
(11)\end{array}$ & $\begin{array}{c}91.40 \\
(117)\end{array}$ & 1.000 & $\begin{array}{l}69.5 \\
(89)\end{array}$ & $\begin{array}{l}21.10 \\
(27)\end{array}$ & $\begin{array}{c}7 \\
(9)\end{array}$ & $\begin{array}{l}0.80 \\
(1)\end{array}$ & $\begin{array}{l}1.60 \\
(2)\end{array}$ & 0.016 \\
\hline
\end{tabular}

Table 6. INR training and monitoring of some drugs by INR examinations

\begin{tabular}{|c|c|c|c|c|c|c|c|c|c|}
\hline \multirow[b]{2}{*}{ Drugs } & \multicolumn{3}{|c|}{ Trained } & \multicolumn{6}{|c|}{ Time of working as physcian } \\
\hline & $\begin{array}{l}\text { Yes } \\
\%(\mathbf{n})\end{array}$ & $\begin{array}{c}\text { No } \\
\%(\mathbf{n})\end{array}$ & $\mathbf{P}$ & $\begin{array}{c}1-5 \text { years } \\
\%(n)\end{array}$ & $\begin{array}{c}\text { 6-10 } \\
\text { years } \\
\%(n)\end{array}$ & $\begin{array}{c}11-15 \\
\text { years } \\
\%(n)\end{array}$ & $\begin{array}{l}16-20 \\
\text { years } \\
\%(n)\end{array}$ & $\begin{array}{l}>20 \\
\%(n)\end{array}$ & $\mathbf{P}$ \\
\hline Dabigatran & $15(9)$ & $85(51)$ & 0.015 & $65(39)$ & $20(12)$ & $\begin{array}{l}10 \\
(6) \\
\end{array}$ & $\begin{array}{c}3.30 \\
(2)\end{array}$ & $\begin{array}{c}1.70 \\
(1)\end{array}$ & 0.616 \\
\hline Clopidogrel & $\begin{array}{r}10.70 \\
(8)\end{array}$ & $\begin{array}{r}89.30 \\
(67) \\
\end{array}$ & 0.303 & $\begin{array}{r}65.20 \\
(49) \\
\end{array}$ & $\begin{array}{r}18.70 \\
(14) \\
\end{array}$ & $\begin{array}{r}10.70 \\
(8) \\
\end{array}$ & $\begin{array}{l}2.70 \\
(2)\end{array}$ & $\begin{array}{c}2.70 \\
(2)\end{array}$ & 0.070 \\
\hline Warfarin sodium & $\begin{array}{r}11.90 \\
(7) \\
\end{array}$ & $\begin{array}{r}88.10 \\
(131) \\
\end{array}$ & 0.209 & $\begin{array}{r}71.40 \\
(60) \\
\end{array}$ & $\begin{array}{r}22.60 \\
(19) \\
\end{array}$ & $\begin{array}{r}3.60 \\
(3)\end{array}$ & $\begin{array}{c}1.20 \\
(1)\end{array}$ & $\begin{array}{c}1.20 \\
(1)\end{array}$ & 0.287 \\
\hline Rivaroxaban & $\begin{array}{r}10.20 \\
(6) \\
\end{array}$ & $\begin{array}{r}89.80 \\
(53) \\
\end{array}$ & 0.520 & $\begin{array}{r}64.40 \\
(38) \\
\end{array}$ & $\begin{array}{r}18.60 \\
(11) \\
\end{array}$ & $\begin{array}{r}10.20 \\
(6) \\
\end{array}$ & $\begin{array}{c}3.40 \\
(2)\end{array}$ & $\begin{array}{c}3.40 \\
(2)\end{array}$ & 0.165 \\
\hline Enoxaparin & $\begin{array}{r}4.90 \\
(4) \\
\end{array}$ & $\begin{array}{l}95.1 \\
(77) \\
\end{array}$ & 0.069 & $\begin{array}{r}71.60 \\
(58) \\
\end{array}$ & $\begin{array}{r}21 \\
(17) \\
\end{array}$ & $\begin{array}{r}3.70 \\
(3)\end{array}$ & $\begin{array}{c}3.70 \\
(3)\end{array}$ & $\begin{array}{c}0 \\
(\mathrm{o})\end{array}$ & 0.191 \\
\hline $\begin{array}{l}\text { Acetylsalicylic } \\
\text { acid }\end{array}$ & $\begin{array}{r}13.10 \\
(8) \\
\end{array}$ & $\begin{array}{r}86.90 \\
(53)\end{array}$ & 0.079 & $68.90(42)$ & $18(11)$ & $\begin{array}{r}8.20 \\
(5) \\
\end{array}$ & $\begin{array}{c}3.30 \\
(2)\end{array}$ & $\begin{array}{c}1.60 \\
(1)\end{array}$ & 0.909 \\
\hline
\end{tabular}

There are a number of risk factors for starting warfarin sodium. In a question we asked physicians, we questioned whether those between the ages of 65 and 74 constituted a risk factor for warfarin sodium initiation. The correct answer was not a risk factor.

A statistically significant relationship was found between the inclusion of an education on anticoagulant therapy and the tracking of INR, and between the age of 65-74 and the validity of opinions about whether the presence of vascular disease was a risk factor for the initiation of warfarin sodium. This is another indicator that shows the importance of the education we discussed in the previous paragraph.

The INR test, which is one of the coagulation tests, is a test that measures the PT and is called International Normalized Ratio. A statistically significant relationship was found 
An Evaluation to the Awareness of Family Medicine Residents in Ankara for the Coagulation Testing, Anticoagulation Treatment and Tracking

between the correctness of the responses to the necessity of having an INR test if participants had a prolonged nosebleed by the time they were physicians. A decline in the rate of correct answers has been found when the duration of the medical practice is over 10 years. As mentioned earlier, it is not possible to give the entire information burden in the medical community in medical faculties. For this reason, physicians should continue their education life after graduation. If these habits are acquired in the course of assistant medicine, it is necessary to continue this habit in the continuation of the medical life. Considering that the lifetime of the learner is maintained, we have learned from our work that FMR have learned to move away from the year of graduation in terms of their assistants. In order to be able to overcome this, there is a need to maintain and encourage continuing medical education.

The probability of developing bleeding anywhere in the gastrointestinal tract in a patient using warfarin was $38.5 \%$ in another study. ${ }^{3}$ Considering this complication, which is such a serious risk, it is necessary to closely observe the symptoms of the patients. When the symptoms of the alarm are detected, the dose adjustment must be reestablished by checking the INR values.

A statistically significant relationship was found between the accuracy of the answers given about the necessity of taking the INR test in case of severe gingival hemorrhage with the duration of the medical practice. The main cause of severe gingival bleeding is platelet dysfunction. When the fibrin breaks in the body mucosa is the anterior plasma, the clot is quickly destroyed and cannot reappear. That's why bleeding takes a long time. It manifests itself in particular in the form of gums and nosebleeds. ${ }^{4} \mathrm{~A}$ patient using warfarin sodium should be awake in the presence of mucosal hemorrhages. And it is imperative to have a gold standard test such as INR. ${ }^{4}$ Here, we can relate the experience of 29 years of 6-10 years of physicians to experience and experience in the profession. However, we see a great sorrow that physicians who are in more and more of a job cannot transfer their experience to practice. Gaining the experience gained is an indispensable truth that will succeed in the medical arts. However, information needs to be replicated for freshness. Physicians do not have experience in the first five years, but there is information, the amount of information that is forgotten in the doctor who has been in medicine for more than 10 years is increasing. But 6-10 years of physicians are both experienced and knowledgeable, so they have a perfect match of knowledge and experience.

One of the cases where INR is mandatory is the unusual increase in menstrual bleeding in women. A statistically significant relationship was found between the accuracy of responses to the need for INR testing if there was an unusual increase in menstrual bleeding and the duration of the medical practice. Dysfunction of platelet function should be considered when encountering bruises which appear as petechiae, purpura and sometimes ecchymosed. First of all, tests such as PT, APTT, INR, bleeding time which measure the ability of clotting should be demanded from these patients, which should not have a complete blood count and peripheral spread. ${ }^{5}$ In patients with medicine time they Participants body in case of hitting the ground that although the lack of bruising in the accuracy of the answers given on the necessity of taking INR test a statistically significant correlation was found. In these two questions, a noticeable increase has been observed in the rates of 6-10 years attending physicians. As we have 
An Evaluation to the Awareness of Family Medicine Residents in Ankara for the Coagulation Testing, Anticoagulation Treatment and Tracking

mentioned before, the medical community we touch means that we have the advantage of the humanity to which we combine education and experience.

The INR assay is a standardized value to allow international use, indicating the time of the prothrombin. ${ }^{6,7}$ Knowing the factors that increase or decrease this value makes it possible for an expert physician to accurately assess the patient and the measurement in front of him and to achieve success in diagnosis and treatment. In particular, right heart failure triggered by hepatic congestion as a venous congestion causes impaired liver function and INR value, that is, prothrombin time. ${ }^{8}$

A statistically significant relationship was found between the duration of the medical care performed by the participants and the correctness of the answers given to the question whether hyperthyroidism and collagen tissue diseases would increase the INR value when the questions of INR value increasing factors were compared with those of the physicians. Here again, physicians who have been practicing medicine for 6-10 years have come to the conclusion that they achieved the right results with a higher percentage than the others. It has come to a conclusion that he has been removed from the response in proportion to the passage of years. A statistically significant relationship was also found between the correctness of the answers given to the question whether the duration of the medical practice would increase the INR value of diarrhea. Here, it was found that the correct answers were as inadequate as $9 \%$. In this question, it is seen that the percentage of the young physicians whose occupational age is not full to years is lower. Physicians experienced with diarrhea seem to have a more accurate approach.

A statistically significant relationship was found between participants' medical history and the correctness of the answers given to the question whether alcohol would decrease INR value. The purpose of this question was whether the issue of whether alcohol could increase or decrease the INR value was known. When asked about the fact that the assistants of family medicine responded in a serious manner in a serious manner such as $9 \%$, the young physicians were following a wrong attitude compared to those who were 15 years old.

A statistically significant relationship was found between the accuracy of the answers given to the question asked whether the patients with warfarin sodium should be referred to an upper step if the INR value was above 5 with the duration of the medicine, and spontaneous gingiva, nasal bleeding, idiopathic or fecal blood. The data we have gained here show us that those who have been medical practitioners for 11-15 years have answered more truthfully about the subject.

A statistically significant relationship was found between the correctness of the answers to the question asked by patients who were taking warfarin sodium and whether they should be referred to an upper step if blood was drawn from the gums, nosebleeds, nipples, urine or feces by self-education with anticoagulant therapy and INR tracking. Education is needed to learn a new knowledge of the nature of the human mind and to repeat learned information. A physician who has been trained in anticoagulant therapy and tracking can add information to this knowledge. He / she will be aware of which diagnoses and which treatments to give to their patients. In our study, we also got a response rate parallel to this. It is obviously expected that the 
An Evaluation to the Awareness of Family Medicine Residents in Ankara for the Coagulation Testing, Anticoagulation Treatment and Tracking

respondents of the participants give the correct answer compared to the ones who do not receive education.

After we talk about the importance of education, let's give a few more striking results that show the high response rate of educated physicians:

A statistically significant relationship was found between the correctness of the answers to the question we asked about the need to be alert when paracetamol was prescribed to the patient using warfarin sodium, with an education about anticoagulant therapy and INR tracking. A statistically significant relationship was also found between the accuracy of the answers to the question we asked about the need to be warned of prescribing tricyclic antidepressants to patients who used warfarin sodium with the participation of an education on anticoagulant therapy and INR in the same way. A statistically significant relationship was found between the accuracy of the answers given to the questions we asked about whether to use the INR test and tracking in the treatment of patients using dabigatran for anticoagulant therapy with an education about anticoagulant therapy and INR tracking. Resident physicians who received training in all three of these outcomes answered correctly about twice the number of non-trained physicians.

In some studies, approximately 100 ooo people each year were found to have had venous thrombosis for the first time in their lives. The annual incidence of vascular thrombosis increases steadily with age, and this incidence is up to $1 \%$ over 85 years. ${ }^{9}$ The situation of thrombosis, which is one of the cases with very high mortality and morbidity, the tracking of the coagulation tests we use, the cases where these tests will be measured abnormally, the last anticoagulant treatments and the adverse conditions encountered during treatment should be well known by primary care physicians.

The results of this study, which we aimed to reveal about the coagulation tests, anticoagulant therapy and tracking awareness of FMR in Ankara, and the need for an additional standard training on this issue in the period of family medicine specialists who will start to work in the first step. We can say that physicians who are trained in anticoagulant therapy and INR tracking in the light of the obtained data are less challenged and less responsive to the questions we ask. Unfortunately, this is not the case in the Family Medicine education curriculum. Based on the results of this study, it is evident that adding "anticoagulant therapy and INR tracking" topics to the family medicine education curriculum, as well as the training of physicians who have already been equipped, will be able to support the knowledge of the educated family medicine specialists.

At the beginning of the research, we had an expectation that the number of doctors who received training would be higher than the number of doctors. However, we reached the conclusion that one-tenth of the participants participated in the training. Although educational standards are one of the criteria to be determined, the lack of such standardization is one of the limitations of our study. The most important foresight in the study of resident assistant physicians responding to the majority, if not all, of the questions. But we have not found a result that meets expectations in this regard. We do not know the nature of the education that is the reason for this, but we can also connect the fact that we do not have knowledge about when the education is taken. 
An Evaluation to the Awareness of Family Medicine Residents in Ankara for the Coagulation Testing, Anticoagulation Treatment and Tracking

When we look at our work in general, the rate of responding to the correct response is gradually decreasing while participants are physicians over 20 years from the first 10 years. Medicine is a dynamic art. It constantly defeats itself. And we are dedicated to be a good physician in the place where we can keep up with these innovations. We can attribute this to the fact that the correct response rate given to this question is more enthusiastic to investigate that it is relatively higher in younger physicians and in the years when the medical career is hungrier to learn. It is necessary to take some measures to encourage new studies to search for an answer as an important finding indicating that the distance from the medical school away from the skills of reading, learning and tracking of new information is far away from the year of graduation and to keep up to date information in case of similar results.

As a result, the need for standardized training in this research has been clearly demonstrated. At the same time, we have shown that FMR can get closer to their patients if they are trained on anticoagulant therapy and tracking. Our work has brought us face to face with the fact that the awareness of anticoagulant treatment and tracking has gradually decreased since the first 10 years of the family medicine residents' professions. Therefore, trainings should be held in order to refresh the information that should be remembered as the years pass. Because of the fact that all resident physicians are specialist students and they are in similar educational environments, there is another issue that should be supported with additional studies in order to search for the answer "Should the undergraduate education be taken into consideration in evaluating the awareness of anticoagulant treatment and tracking".

\section{References}

1. Leach DC, Fletcher SW. Perspectives on continuing education in the health professions: improving health care through lifelong learning. Chest. 2008;134(6):1299-303.

2. Van Cott EM, Laposata M, Prins MH. Laboratory evaluation of hypercoagulability with venous or arterial thrombosis. Archives of pathology \& laboratory medicine. 2002;126(11):1281-95.

3. Fanikos J, Grasso-Correnti N, Shah R, Kucher N, Goldhaber SZ. Major bleeding complications in a specialized anticoagulation service. The American journal of cardiology. 2005;96(4):595-8.

4. Doree C, Stanworth S, Brunskill SJ, Hopewell S, Hyde CJ, Murphy MF. Where are the systematic reviews in transfusion medicine? A study of the transfusion evidence base. Transfusion medicine reviews. 2010;24(4):286-94.

5. Bonar RA, Lippi G, Favaloro EJ. Overview of Hemostasis and Thrombosis and Contribution of Laboratory Testing to Diagnosis and Management of Hemostasis and Thrombosis Disorders. Methods in molecular biology. 2017;1646:3-27.

6. Kraaijpoel N, van Es N, Bleker SM, Brekelmans MPA, Eerenberg ES, Middeldorp S, et al. Clinical Impact and Course of Anticoagulant-Related Major Bleeding in Cancer Patients. Thrombosis and haemostasis. 2018;118(1):174-81.

7. Kucher N, Castellanos LR, Quiroz R, Koo S, Fanikos J, Goldhaber SZ. Time trends in warfarinassociated hemorrhage. The American journal of cardiology. 2004;94(3):403-6.

8. Hunt PJ, Richards AM, Espiner EA, Nicholls MG, Yandle TG. Bioactivity and metabolism of Ctype natriuretic peptide in normal man. The Journal of clinical endocrinology and metabolism. 1994;78(6):1428-35.

9. Costantino G, Ruwald MH, Quinn J, Camargo CA, Jr., Dalgaard F, Gislason G, et al. Prevalence of Pulmonary Embolism in Patients With Syncope. JAMA internal medicine. 2008. 